\title{
IMPORTANCE OF PERIODIC HEALTH CHECK UP FOR INDIAN WOMEN
}

\author{
Avtar Singh Bansal' ${ }^{1}$, M. P. Cariappa 2 , R. K. Gupta ${ }^{3}$, Rajshree Gupta ${ }^{4}$
}

\section{HOW TO CITE THIS ARTICLE:}

Avtar Singh Bansal, M. P. Cariappa, R. K. Gupta, Rajshree Gupta. "Importance of Periodic Health check up for Indian Women". Journal of Evolution of Medical and Dental Sciences 2014; Vol. 3, Issue 28, July 14;

Page: 7853-7860, DOI: 10.14260/jemds/2014/2983

ABSTRACT: OBJECTIVE: In the past women's health care services were focused mainly on the health problems during pregnancy and childbirth. Although these are major contributors of morbidity and mortality in women life and require to be addressed in correct perspective, but at the same time the question arises that why should women's health remain limited to traditional Maternal and Child Health issues, as they are also exposed to strong risks of lifestyle diseases and specific conditions like certain cancers, anaemia, besides hazards of pregnancy/ child birth. Due largely to asymptomatic nature of these conditions, women may not be aware that they are at risk for non-communicable diseases, therefore screening for these diseases are important for assessing risk of future medical problems and to encourage a healthy lifestyle by women. MATERIAL AND METHODS: At the outset, to sensitize the women regarding importance of health check-up, health awareness campaign was run, followed by health examination including anthropometry, general medical checkup, blood tests for haemoglobin, blood sugar, ( Random), serum cholesterol, urine test for albumin and sugar, clinical breast examination for presence of lump and PAP smear for cervical cancer. Subjects with abnormal results were counseled by counselor and referred for further managements. SAMPLING: 1760 females married to Armed Forces personnel between the ages of 22 years to 55 years of age were selected for screening excluding pregnant women. 1384 women participated in the study. RESULTS: The prevalence of various parameters studied was comparable to national figures and other studies. CONCLUSION: Results suggest that women are vulnerable to lifestyle diseases, certain cancers and non-communicable diseases. Strict preventive measures and health education is mandatory to limit this menace; a formalized periodic health check up for women in different age groups is strongly recommended.

KEYWORDS: Disease Screening, Periodic medical check-up, lifestyle diseases, Cervical cancer, breast Cancer.

INTRODUCTION: Constitution of India provides equal rights to women, however due lack of acceptance from the male dominant society, Indian women are not as privileged as men and are not treated equal and their priorities for health remains low and intrinsically linked to their status in society. In the past, work on women's health was primarily focused on the health problems during pregnancy and childbirth. However gender-based approach to health care has broadened the understanding of women's health problems and helped to identify ways to address them for women of all ages. ${ }^{1}$

As the life expectancy of females in India has increased from 23.96 years in1901 to 66.90 in 2011 , that has lead to increase in health problems of aging and rise of non-communicable diseases amongst women which represents one of the major health challenges. Till recent past, control and prevention of communicable diseases was emphasized. Attention has now shifted to control and prevention of non-communicable diseases including stroke, hypertension and coronary artery 
disease at the national level. Rising affluence has modified the dietary pattern characterized by increased consumption of diets rich in fat, sugar and calories; change in life style, increasing stress of modern life has led to rapid rise of non-communicable diseases amongst women.

Women's body changes throughout her life time, from fetal development to post menopause hence there is increasing need for age related regular health check up by screening for health. Cardiovascular diseases are now known to be a major cause of death among women.

However, this is not well recognized, leading to delays in treatment-seeking and diagnosis among women. The identification of gender differences in cardiovascular disease has made it possible to develop more effective health promotion and prevention strategies that have improved women's health in many countries.

MATERIAL \& METHODS: The present study was undertaken to survey the health status for certain defined non communicable diseases of women living in a military station in the state of Jammu and Kashmir. Total 1384 married women of between the age of 20 yrs to 55 yrs of army personnel participated in the study out of 1730 women ( $n=1384,77.57 \%)$ present in the garrison.. The study duration was from 06 Jun to 11 Jun 2011. List of all houses in the garrison was obtained and listed for study. Army being controlled population, hence the health check was carried out in a planned manner by calling and doing health check- up for 40-45 women in a day at a military hospital The study was conducted in four phases.

Phase I: Health Awareness Campaign: A health education campaign for women was organized in the area of study in May 2011. Women in different locations were collected in their respective five strategic locations on different days and made aware of the health risks they are exposed to and as to why their health examination, at least once a year is mandatory. A Family Health Record Card documenting details of various examinations to be carried out was designed.

Phase II: Conduct of Programme: Health examination was conducted at a military hospital near Jammu. All women underwent basic anthropometric measurements (height, weight, BMI) followed by general medical examination including measurement of blood pressure. They were tested for haemoglobin and routine tests of urine sample. Women above the age of 35years were tested for random blood sugar, serum cholesterol, breast examination for lump and PAP smear.

Phase three consisted of reporting and in Phase four follow up was done for treatment of cases found positive for any ailment. The BMI was computed and the body weight status of each individual was classified in accordance with the WHO classification; overweight was defined as BMI of $25.0-29.9 \mathrm{~kg} / \mathrm{mt}^{2}$ and obesity as $\geq 30 \mathrm{~kg} / \mathrm{mt}^{2}{ }^{[2]}$

Women were labeled as "pre-hypertensive" those with BP ranging from 120-139 $\mathrm{mmHg}$ systolic and/or 80-89 mmHg diastolic. Blood pressure $>140 / 90 \mathrm{~mm}$ of $\mathrm{Hg}$ was labeled as case of hypertension. This new designation is intended to identify those individuals in whom early intervention by adoption of healthy lifestyles could reduce BP, decrease the rate of progression of BP to hypertensive levels with age, or prevent hypertension entirely. ${ }^{3}$

Anemia was graded as Mild anaemia (10.0-10.9 grams/decilitre for pregnant women and $10.0-11.9 \mathrm{~g} / \mathrm{dl}$ for non-pregnant women, Moderate anaemia $(7.0-9.9 \mathrm{~g} / \mathrm{dl})$, and Severe anaemia $(<7.0$ 
$\mathrm{g} / \mathrm{dl})^{4}$ Serum Cholesterol was labeled as borderline high $(200-239 \mathrm{mg} / \mathrm{dl}) ; \mathrm{High}>240 \mathrm{mg} / \mathrm{dl}{ }^{5}$ and hyperglycemia was based on Blood Sugar Random > 200mg/dl. ${ }^{6}$

SAMPLING: All the 1384 out of 1730 women present in the military camp area participated in the study. These women belonged to different states of India and are rotated every two years due to the posting system leading to mixture of army soldiers and their families from all over India. Demographic data for those aged 22 years and over are shown in Table 1.

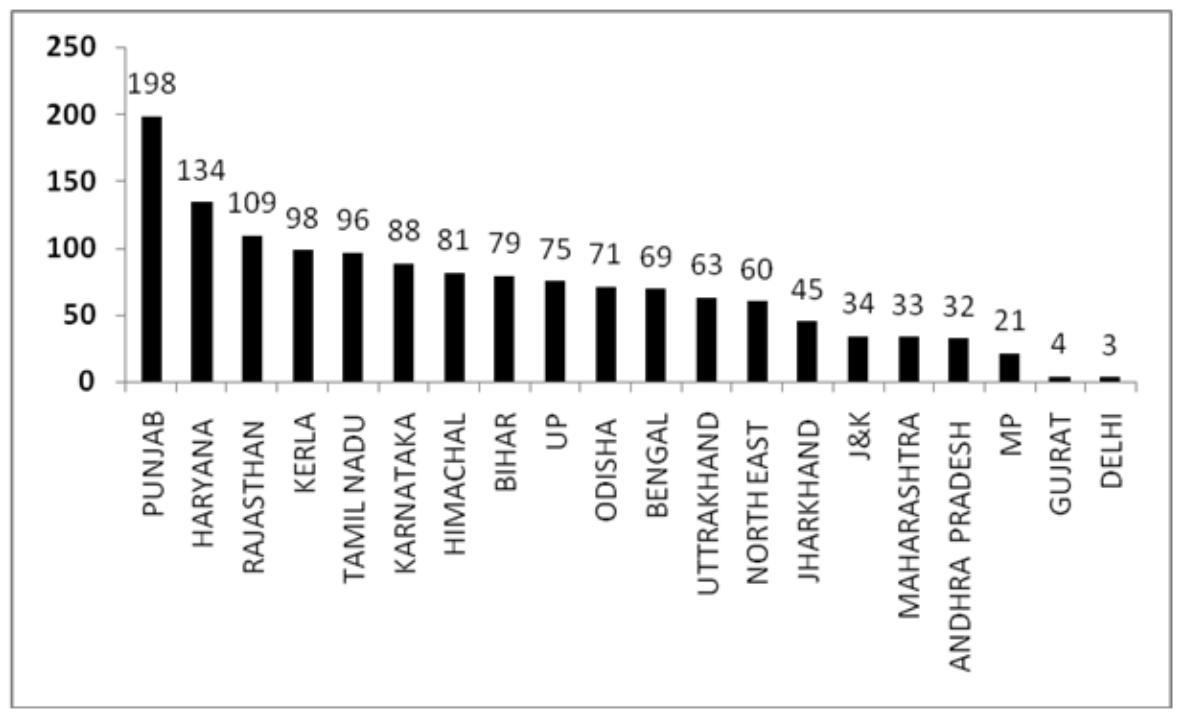

Table 1: Demographic profile of participants

RESULTS: Total 1384 women from different parts of India participated in the survey. Age profile of participants as per Table 2 shows that the age of youngest participants were 22 years and oldest was 56 years.

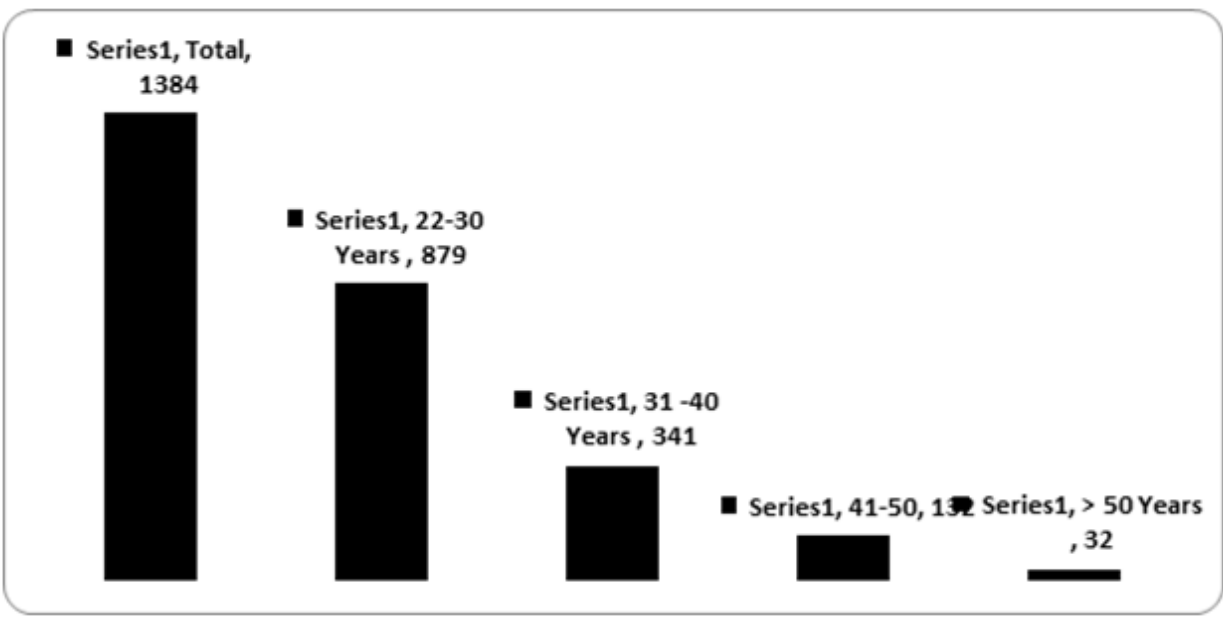

Table 2: Age distribution of participants 
Education is a fundamental means to bring any desired change in society, which is an accepted fact throughout the world. The literacy rate before independence was $2.6 \%$ and as per 2011 Census the male literacy rate is 82.14 while female literacy rate is 65.46 . In the sample population only 0.79 percent women were literate and majority $68.21 \%$ have been to high school, $17.27 \%$ were graduates. Detail of education qualifications is given in Table No. 3.

\begin{tabular}{|l|c|c|}
\hline \multicolumn{1}{|c|}{ Education } & Numbers & Percent \\
\hline Literate & 11 & 0.79 \\
\hline Primary School & 145 & 10.48 \\
\hline High School & 944 & 68.21 \\
\hline Graduate & 239 & 17.27 \\
\hline Post Graduate & 45 & 03.25 \\
\hline \multicolumn{1}{|c|}{ Total } & $\mathbf{1 3 8 4}$ & $\mathbf{1 0 0 . 0 0}$ \\
\hline
\end{tabular}

Table 3: Educational profile of participants

The range of age was 22 years to 54 Years with mean of 29.8, Mean income of the families was Rupees 27, 053. The weight range was 36 Kilograms to 108 Kilograms. Systolic blood pressure range measured from $106 \mathrm{~mm}$ of $\mathrm{Hg}$ to $170 \mathrm{~mm}$ of $\mathrm{Hg}$ whereas diastolic blood pressure mean was 78.5 with range of $66 \mathrm{~mm}$ of $\mathrm{Hg}$ to $116 \mathrm{~mm}$ of $\mathrm{Hg}$. Values of hemoglobin ranged from $7.2 \mathrm{mg} / \mathrm{dl}$ to $14.4 \mathrm{mg} / \mathrm{dl}$ with mean of $8.2 \mathrm{mg} / \mathrm{dl}$. Serum cholesterol ranged from $132 \mathrm{Mg} / \mathrm{dl}$ to $246 \mathrm{mg} / \mathrm{dl}$ with mean of 164.3 $\mathrm{mg} / \mathrm{dl}$ whereas Blood Sugar (random) values mean was $66.6 \mathrm{mg} \%$ with a range of $56.4-146.8 \mathrm{mg} \%$

\begin{tabular}{|l|c|c|}
\hline \multicolumn{1}{|c|}{ Parameter } & Range & Mean \\
\hline Age (years) & $22-54$ & 29.8 \\
\hline Monthly income (Rs) & $20,000-90,000$ & 27,053 \\
\hline Weight (Kg) & $36-108 \mathrm{~kg}$ & $53.4 \mathrm{~kg}$ \\
\hline Blood Pressure Systolic (mmHg) & $106-170$ & 126.6 \\
\hline Blood Pressure Diastolic (mmHg) & $66-116$ & 78.5 \\
\hline Haemoglobin (g/dl) & $7.2-14.4$ & 8.2 \\
\hline Serum Cholesterol (mg/l) & $132-246$ & 164.3 \\
\hline Blood Sugar (R) & $56.4-146.8$ & 86.6 \\
\hline \multicolumn{2}{|c|}{ Table 4: Investigation and other Parameters } \\
\hline
\end{tabular}

Obesity is increasing at an alarming rate and research on obesity in India has found prevalence to be higher among women. In the present study total $19.59 \%(n=270)$ women were found either overweight or obese. On further analysis the prevalence of overweight amongst participants having BMI of 25 to 30 was 14.02 percent and 5.49 percent women were found obese with BMI more than 30 as given in table No. 5 .

\begin{tabular}{|c|c|c|c|c|}
\hline BMI & 25-29 & Percentage & $\mathbf{> 3 0}$ & Percentage \\
\hline \multicolumn{2}{|c|}{ Age Group } & & & \\
\hline $20-30$ & 47 & 3.40 & 17 & 1.23 \\
\hline $31-40$ & 76 & 5.49 & 31 & 2.24 \\
\hline $41-50$ & 53 & 3.83 & 22 & 1.73 \\
\hline$>50$ & 18 & 1.30 & 4 & 0.29 \\
\hline Total & $\mathbf{1 9 4}$ & $\mathbf{1 4 . 0 2}$ & $\mathbf{7 6}$ & $\mathbf{5 . 4 9}$ \\
\hline
\end{tabular}

Table 5: Overweight and obesity amongst women 
Pre hypertension (BP $>120$ and/or $>80 \mathrm{mmHg}$ ) prevalence was detected in 12.13 percent of women whereas prevalence of hypertension using revised criteria (BP > 140 and/or $>90 \mathrm{mmHg}$ ) was 13.65 percent. Prevalence of anaemia $(<12 \mathrm{~g} / \mathrm{dl}$ for non-pregnant $\&<11 \mathrm{~g} / \mathrm{dl}$ for pregnant women) was observed in 38.70 percent women. 304 (21\%) women more than 35 years of age underwent additional clinical examination for presence of breast lump and investigations for serum cholesterol, random Blood Sugar and PAP smear to detect cervical cancer.

\begin{tabular}{|l|c|c|c|}
\hline \multicolumn{1}{|c|}{ Parameters } & \multicolumn{3}{c|}{ Results } \\
\hline & n & Positive & \% \\
\hline Overweight $\left(\mathrm{BMI} 25-30 \mathrm{~kg} / \mathrm{m}^{2}\right)$ & 1384 & 194 & 14.02 \\
\hline Obese (BMI $>30 \mathrm{~kg} / \mathrm{m}^{2}$ ) & 1384 & 76 & 5.49 \\
\hline Pre-hypertension & 1384 & 168 & 12.13 \\
\hline Hypertension & 1384 & 189 & 13.65 \\
\hline $\begin{array}{l}\text { Anaemia (<12g/dl for non-pregnant \& } \\
<11 \mathrm{~g} / \text { dl for pregnant women) }\end{array}$ & 1384 & 536 & 38.70 \\
\hline Cholesterol borderline high (200-239mg/dl) & 304 & 47 & 15.46 \\
\hline Cholesterol high (>240 mg/dl) & 304 & 9 & 2.96 \\
\hline Hyperglycemia (>200mg/dl) & 304 & 19 & 6.25 \\
\hline Breast Lump & 304 & 11 & 3.61 \\
\hline PAP Smear (Non-specific inflammation) & 287 & 16 & 6.20 \\
\hline PAP Smear (Epithelial abnormalities) & 287 & 2 & 0.69 \\
\hline
\end{tabular}

Table 6: Results of the Study

Borderline high serum cholesterol $(200-239 \mathrm{mg} / \mathrm{dl})$ was detected in $15.46 \%$ females; however $2.96 \%$ participants had serum cholesterol values more than $240 \mathrm{mg} \%$. While undertaking random blood sugar values it was observed that $6.25 \%$ had blood sugar values more than $200 \mathrm{mg} / \mathrm{dl}$. On clinical examination of breasts, 11 (3.61\%) women had palpable lumps. PAP smear could be undertaken for 287 women as 17 women were not conforming the criteria for PAP smear due to menstrual periods.6.20 \% participants' PAP smear showed Non-specific inflammation and only 0.69 $\%$ were having epithelial abnormalities in the microscopic examination vide table 6.

DISCUSSION: OBESITY: In present study overweight amongst participants (BMI > 25) was $14.02 \%$ and $5.49 \%$ women (BMI > 25) were found obese. The studies conducted by National family health survey (NFHS-2) in 1998-1999 and NFHS-3 in 2005-2006 indicates that prevalence of obesity among Indian women has increased from $10.6 \%$ to $12.6 \%$ (increased by $24.52 \%$ ). Prevalence of obesity was more amongst women residing in cities (23.5\%), having high qualification (23.8\%), and belonging to Sikh community (31.6\%) and households in the highest wealth quintile (30.5\%). Highest percentage of obese women is found in Punjab (29.9\%).4

In a study conducted by Anuradha et al the prevalence of overweight (BMI $\geq 23$ ) was $27.7 \%$ (95\% confidence interval [CI] 24.3-32.2) and the prevalence of obesity (BMI $\geq 25$ ) was 19.8\% (95\% CI 16.5-23.6) 7 The present group of participants were conglomeration of women representing many Indian states and union territories with major contribution from wealthy states like Punjab, Haryana, Kerala thus the percentage of women with overweight / obesity is above National average. 
ANAEMIA: Anaemia is the most common nutritional deficiency disorder in the world and it was observed in 37.04 percent of women participants of the present survey which is lower than national surveys. In NFHS II 52 percent of women had some degree of anaemia. ${ }^{8}$

Thirty-five percent of women are mildly anaemic, 15 percent are moderately anaemic, and 2 percent are severely anaemic. The National Family Health Survey III conducted in 2005-06 brought out that more than half of women in India (55.3\%) are anaemic. On further analysis it is documented that $38.6 \%$ women were mild anaemic ( $\mathrm{Hb} 10-11.9 \mathrm{Gm} / \mathrm{dl}) 15 \%$ moderately anaemic (Hb $7.00-9.9$ $\mathrm{Gm} / \mathrm{dl})$ and $1.8 \%$ severely anaemic $((\mathrm{Hb}<7 \mathrm{Gm} / \mathrm{dl})$. WHO has estimated that prevalence of anaemia in developed and developing countries in pregnant women is 14 per cent in developed and 51 per cent in developing countries and 65-75 per cent in India. ${ }^{9}$

HYPERTENSION: Present study using revised criteria has shown that prevalence of pre hypertension among participants was $12.13 \%$ and $13.65 \%$ women were hypertensive As per the study of Sushil K. Bansal et al the hypertension, was present in 30.9\% (95\% CI 25.6 to 36.0 ) of males and $27.8 \%$ (95\% CI 23.4 to 32.2) of females. ${ }^{10}$

Whereas the studies by Gupta $\mathrm{R}$ shown a high prevalence of hypertension among urban adults: men 30\%, women 33\% in Jaipur (1995), men 44\%, women 45\% in Mumbai (1999), men 31\%, women 36\% in Thiruvananthapuram (2000), 14\% in Chennai (2001), and men 36\%, women 37\% in Jaipur (2002). Among the rural populations, hypertension prevalence is men $24 \%$, women $17 \%$ in Rajasthan (1994). Hypertension diagnosed by multiple examinations has been reported in $27 \%$ male and 28\% female executives in Mumbai (2000) and 4.5\% rural subjects in Haryana (1999). ${ }^{11}$

DIABETES: Hyperglycemia was recorded among 6.25percent women. The NFHS III report States that according to self-reports, over two percent of women and men age 35-49 are suffering from diabetes. The number of women who have diabetes ranges from 282 per 100, 000 women in Rajasthan to 2, 549 per 100, 000 women in Kerala. In five other states (Tamil Nadu, Goa, Tripura, West Bengal, and Delhi) the number with diabetes is relatively high (above 1, 500 per 100, 000 women). None of the states in the Central Region have prevalence levels above 1, 000 per 100, 000 women. Rajasthan, Uttar Pradesh, Assam, and Maharashtra all have diabetes prevalence levels below 500 per 100, 000 women. ${ }^{4}$

CANCERS: Cancer has become one of the ten leading causes of death in India. Breast cancer is the most common diagnosed malignancy in India, it ranks second to cervical cancer. ${ }^{12}$ In this study 304 women were examined for breast lump and 11 women $(3.61 \%$ ) had breast lump. PAP smear was undertaken for 287 women and $6.20 \%$ were positive for inflammatory reaction and $0.69 \%$ showed epithelial changes.

Report published by Registrar General of India states cervical cancer is the leading cause of cancer death in women in both rural and urban areas. The cervical cancer death rate of 16 per 100 000 reported suggests that a 30 -year old Indian woman has about $0.7 \%$ risk of dying from cervical cancer before 70 years of age in the absence of other diseases. By contrast, the risk of dying during pregnancy for Indian women aged $15-49$ years is about $0 \cdot 6 \% .{ }^{13}$ 
LIPIDS: Borderline high serum cholesterol $(200-239 \mathrm{mg} / \mathrm{dl})$ was detected in $15.46 \%$ females; however $2.96 \%$ participants had serum cholesterol values more than $240 \mathrm{mg} \% .18 \mathrm{~K}$ Goswami et al in his study in Kolkota observed mean Cholesterol value amongst females $189.8 \pm 38.2$ SD. ${ }^{14}$

CONCLUSION: Present study brings outs fact that presence of many non-communicable diseases amongst women go undetected unless a system of routine health check-up for is implemented. Advice on common conditions amongst Indian women like anaemia, easily detectable cancers and life style diseases bring immense benefit to community.

Timely detection and prevention of dangerous conditions like carcinomas of breast and cervix, and debilitating conditions like obesity, hypertension, diabetes mellitus and IHD is a cost effective measure of health care delivery. Delay in diagnosis and treatment of these preventable will lead to increased healthcare costs further leading to worsening the poverty as families have to pay for more long-term healthcare services, medications, and rehabilitation.

Gender equality is more appropriate concept to use in context of health. Policies and programmes should aim at achieving gender equality in health through appropriate investments and designs to be able to meet health needs of women and men to overcome the effect of discrimination. ${ }^{15}$

It is recommended that a comprehensive health policy be considered by policy makers to include appropriate intervention strategies for regular health screening of Indian women for common and preventable cancers and lifestyle diseases and to achieve the same the health care personnel must be actively involved in providing health education regarding life style modification and importance of screening for common cancers.

\section{REFERENCES:}

1. What is a gender-based approach to public health? Online Q \& A 7 March 2007 http://www.who.int/features/qa/56/en/index. html 29 Dec 2013.

2. WHO Expert committee. Physical status: The use and interpretation of anthropometry. WHO Technical Report Series 894, 1995. p. 47.

3. Chobanion AV, Bakris GL, Black HR. The seventh report of the joint national committee on prevention, detection, evaluation, and treatment of high blood pressure- The JNC 7 report. JAMA. 2003; 289: 2560-2572

4. International Institute for Population Sciences (IIPS) and Macro International. 2007. National Family Health Survey (NFHS-3) India, 2005-06: (1)

5. Executive Summary of the Third Report of The National Cholesterol Education Program (NCEP) Expert Panel on Detection, Evaluation, And Treatment of High Blood Cholesterol In Adults] JAMA. 2001 May 16; 285 (19): 2486-97

6. Fonseca V, Inzucchi SE, Ferrannini E. Redefining the Diagnosis of Diabetes Using Glycated Hemoglobin Diabetes Care July 2009 32: 1344-1345; doi: 10.2337/dc09-9034.

7. Anuradha R. Dr. Ravivarman G. Dr. Timsi Jain: The Prevalence of Overweight and Obesity among Women in an Urban Slum of Chennai Journal of Clinical and Diagnostic Research. 2011 October, Vol-5 (5): 957-960

8. International Institute for Population Sciences (IIPS) and Macro International. 2007. National Family Health Survey (NFHS-2), 1998-09: India: Key Findings Mumbai: IIPS. Pp 19 
9. DeMayer EM, Tegman A. Prevalence of anaemia in the World. World Health Organ Qlty 1998; 38: 302-16

10. Sushil K. Bansal et al the prevalence of hypertension and hypertension risk factors in a rural Indian community: A prospective door-to-door study: J Cardiovascular Dis Res. 2012 Apr-Jun; 3 (2): $117-123$

11. Gupta R. Trends in hypertension epidemiology in India. J Hum Hypertension. 2004 Feb; 18 (2): 73-8.

12. Kamath R, Mahajan KS, Ashok L, Sanal T S. A study on risk factors of breast cancer among patients attending the tertiary care hospital, in Udupi district. Indian J Community Med, 2013 [cited 2013 Dec 26]; 38: 95-9.)

13. Registrar General of India. Special bulletin on maternal mortality in India 2007-2009. http://www.censusindia.gov.in/vital_statistics/

14. Goswami K, Bandyopadhyay A. Lipid profile in middle class Bengali population of Kolkota. Indian J Clin Biochem. 2003; 18 (2): 127-30

15. Sen G, Ostlin P, Unequal, unfair, ineffective and inefficient. Gender-inequity in health: why it exists and how we can change it. Final report to the WHO commission on Social Determinants of Health, September 2007, Geneva, World Health Organisation, 2007.

\section{AUTHORS:}

1. Avtar Singh Bansal

2. M. P. Cariappa

3. R. K. Gupta

4. Rajshree Gupta

\section{PARTICULARS OF CONTRIBUTORS:}

1. Professor, Department of Community Medicine, Adesh Institute of Medical Sciences and Research, Bathinda, Punjab.

2. Reader, Department of Community Medicine, AFMC, Pune.

3. Professor, Department of Community Medicine, ACMS, Delhi.

4. Project Manager, Med Education, Department of Community Medicine, AD Instruments, New Delhi.

\section{NAME ADDRESS EMAIL ID OF THE CORRESPONDING AUTHOR:}

Dr. Avtar Singh Bansal,

Professor,

Department of Community Medicine, Adesh Institute of Medical Sciences and Research, Bathinda, Punjab.

Email: avtarsinghbansal@gmail.com

Date of Submission: 02/07/2014.

Date of Peer Review: 03/07/2014.

Date of Acceptance: 07/07/2014.

Date of Publishing: 12/07/2014. 